地すべり地中の埋木の年代測定と地すべりの周期について

林 徳 煌* 山口 真一**

\title{
The Decision of Moving Cycle of Landslides in Past Time by the Age Measurement of Bogwood Obtained from Landslide Area
}

by Lin Teh Hung and shin-ichi Yamaguchi

\section{§1. はしがき}

緩慢な地すべり地が急激な崩壊に変じて新らしい地表 面を生じたときとか，集水井工法などで梁く掘り下げて いった場合など，埋木を発見することがままある。見た 外見はあまり腐蝕してお㥂らず，ほんの数年または数十年 前の崩壊で埋められたかのごとき感じがする。たまたま 徳島県木屋平村森遠地すべり地で集水井くっさく中発見 された埋木を学習院大の木越研究室で ${ }^{14} \mathrm{C} に よ る$ 年代測 定を打願いしたところ15400年 \pm 400 年といら結果が得ら れそその意外に古いことに驚かされた。たまたま著者の 一人が台湾大学物理教室に滞在中, ここに非常に優秀で 国際的に認められた年代測定の研究グループおよび装置 のあることが分った。ちょうどその頃（昭和 44 年 4 月 26 日）死者 8 名, 人家 10 戸の儀牲を出して著名になった新 潟県北魚沼郡広神村水沢新田の地すべり地に巨大な埋木 の発見されたことを知っていたので早速送付して鿓い測 定を行なった。採取は 45 年 3 月 12 日に行なわれた。その

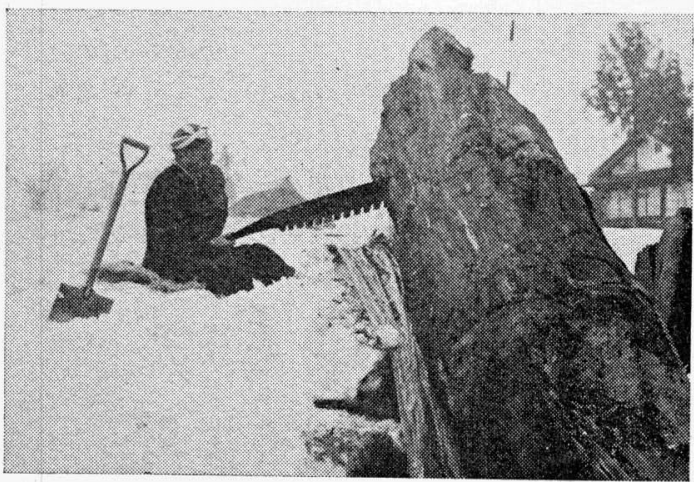

写真-3 埋木より供試体採取状況, 昭和 45 年 3 月 12 日 結果も意外と大きく $1370 \pm 40$ 年であった。年代測定の理 論は簡単であるが，実際の操作は難かしく装置があって もなかなか実際に可動しているところは少ない。

地すべり関係で年代測定を行なった話は未だ聞いてい ないのでこの優秀な測定法を紹介し，後半では地すべ りの周期について論じてみた。

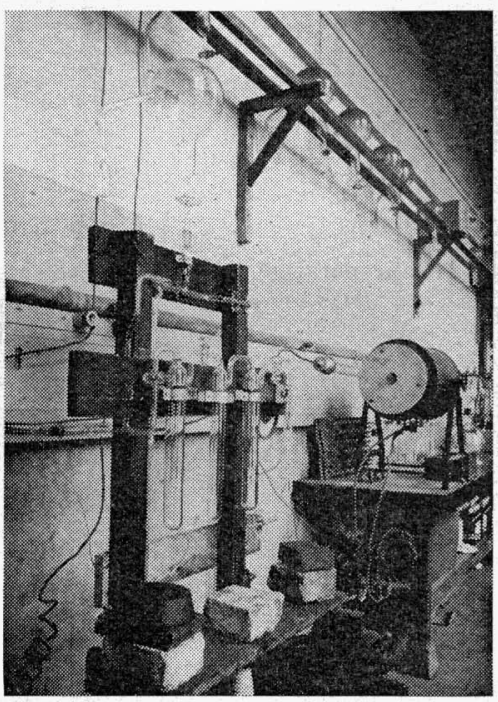

写真-1 台湾大学年代测定室 試料老燃焼させて生成せる $\mathrm{CO}_{2}$ ガスを $\mathrm{CaCO}_{3}$ として集め $\mathrm{CaCO}_{3}$ を加熱分解させて，再び $\mathrm{CO}_{2}$ Kして液体 $\mathrm{N}_{2}$ て冷却しドライアイスとし て精製，測定用 $\mathrm{CO}_{2}$ にしてフラスコに集める。

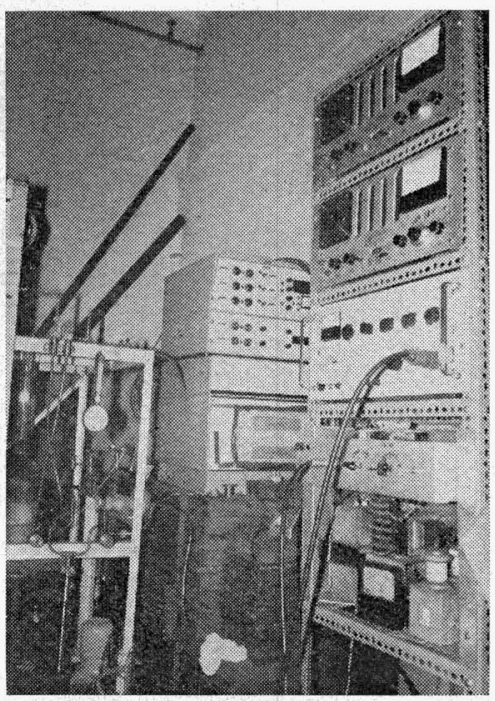

写真-2 台湾大学年代測定室 測定用 $\mathrm{CO}_{2}$ をガスカウンターにつめて，約 50 時間掛けて測定する。

\section{$\S 2$. 年代測定の原理に ついて}

自然界に宇宙線の中性子によ って大気の上層で炭素14が生成 され，これが炭酸ガスの形で存 在することが 1947 年 Libbyに よって明らかにされた。通常大 気中に存在する炭酸ガスは生物 の呼吸, 火山, 温泉, 噴気孔な どによる地球内部からの供給源 があり，これに成層圈から供給 される放射能をもった炭素14炭 酸ガスの量はほぼ一定で，常に 一定量の炭素14が炭酸ガス中に 含まれていたことがわかる。し かし19世紀の後半頃から人類の 消費する石炭, 石油量が急増し たため,ここから供給された炭

* 台海大学理学院化学系技士 ** 京都大学防災研究所教授 
酸ガスによって, 放射能をもつ炭装14の濃度が $2 \%$ 薄められていることが測定されている。これはSuess 効 果と呼ばれている。この炭酸ガスの供給と消費による大 気中の炭酸ガス量の釣り合いは生物を媒介として形成さ れる大きなサイクルによって現仼ほぼ平衡に達している ものと考えられる。植物は生きている間は絶えず新しい 炭酸ガスを取り入れて, 同化作用を営むので空気中の炭 装14と植物体中の炭䕀14灌度はほとんど同じである。

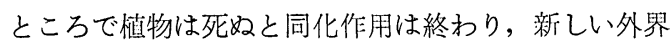
の炭倠14の補給が終わるので遗骸中に固定された炭䋕14 は腐敗か燃焼によって炭酸ガスとなって放出されない限 りのがれられずその半減赥約5600年によって $\beta^{-}$崩壊し, 次第に減少するばかりである。すなわち植物体中の炭菜 14の濃度を测定して，それを現在生さている植物体中の 炭菜14とくらべれば，その植物が死んでから現在までの 過経年数がわかる。

\section{§ 3. 測定について}

\section{1 木片試料の燃焼}

まず木片をルツボに入れ，加熱炭化して得られた木炭 を酸瑟気流中で燃烧させ，完全燃焼して得られた二酸化 炭菜を $6 \mathrm{~N}$ アンモニア水に吸収させて回収した。二酸化 炭菜を吸収したアンモニア水を約 $80^{\circ} \mathrm{C}$ に加㷫し，同じ く $80^{\circ} \mathrm{C}$ に加熱した反応量の塩化カルシウム溶液を加え て，二酸化炭素を炭酸カルシウムとして沈澱させ，滤別 した沈澱に填酸を滴加して, 発生する二酸化炭素をまた アンモニア水に吸収させ, 前と同じく, 再び炭酸カルシ ウムの沈港として回収した。さらに精製するため, 沈測 を熱水中に奬濁して，吸引㴓過，水洗の操作をくり返し 水洗波液に $\mathrm{Cl}$ 一反応がなくなるまで沈測を洗滌した。こ の水洗操作は最後に生成して炭酸ガスの純度を左右し, 微量不純物が計数管の特性を大きく变化させて, 測定結 果に大きな誤差を引き起すので特に注意して行なった。

\section{2 Modern Carbon Standard の作り方}

Modern standard としてはアメリカの National
Bureau of Standard が出している年代测定用として众 定済みの標準シュウ酸を用いた。まず $30 \mathrm{~g} の \mathrm{NBS} シ ュ$ ウ酸を $300 \mathrm{ml}$ の $\mathrm{H}_{2} \mathrm{O}$ に溶解し, フラスコに入れて, $160 \mathrm{ml} 6 \mathrm{~N} \mathrm{H}_{2} \mathrm{SO}_{4}$ を加え, 酸颉ガスを通しながら $550 \mathrm{~m} l$ の $4 \% \mathrm{KM}_{\mathrm{n}} \mathrm{O}_{4}$ 溶液を滴加して炭酸ガスを発生させ，木 片試料と同じく，炭酸カルシウムを作った。

\section{3 Dead Carbon の作り方}

大理石に埕酸を滴加して発生する二酸化炭素を集め て，木片試料と同じように処理して作った。

\section{4 測定用二酸化炭素の発生}

乾燥純炭酸カルシウム約 $15 \mathrm{~g}$ を不英管に入れ, $10^{-3} \mathrm{~mm}$ $\mathrm{Hg}$ に減王しながら $500^{\circ} \mathrm{C} て ゙ 5$ 時閏加熱した後, $750^{\circ} \mathrm{C}$ で10分間加熱して微量の水分と酸䋕を除き，水分は dry

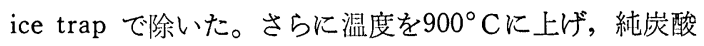
カルシウムを加熱分解, 発生した二酸化炭菜を liquid air trap で固化して集めた後, 蒸発気化させて出した純二酸 化炭素で先に 3 圆聍闌用フラスコを洗ってから注入聍蔵 した。聍蔵フラスコから比例計数管内に注入するときは フラスコの一部を liquid air で泠却して二酸化炭装を固 化し,フラスコは，比例計数管と同じく先に $10^{-5} \mathrm{~mm}-\mathrm{Hg}$ に滅止して残留ガスを完全に除いてから注入した。

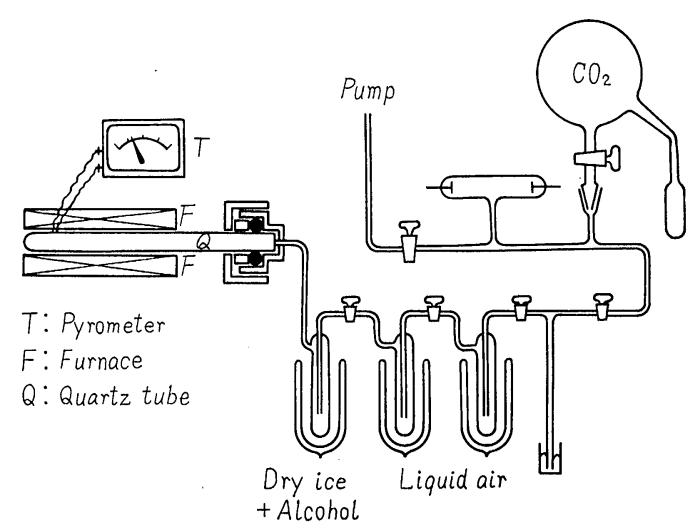

Fig. 2 Apparatus for preparation of carbon dioxide

\section{5 測定装置}

放射能の測定誤差として測定機械から出 て来る悞差たとえば noise 以外に考えられ るものに，宇宙線が測定管を透過して測定 ガスを電離させて発生する誤差がある。そ れで透過力の強い宇宙線を防ぐために測定 管を厚さ $25 \mathrm{~cm}$ の鉄板で完全に囲い，その 上測定管のまわりに gas flow counter を取 りつけ，透過して来る宇宙線を計測して anticoincidence circuit によって，宇宙線 による計測值を差し引いている low back groun counter が用いられている。

(1) 中心比例計数管

内径 $4.4 \mathrm{~cm}$, 長さ $60 \mathrm{~cm}$ の銅管から成り,
$\mathrm{H}_{2} \mathrm{O}$

Fig. 1 Apparatus for combustion 


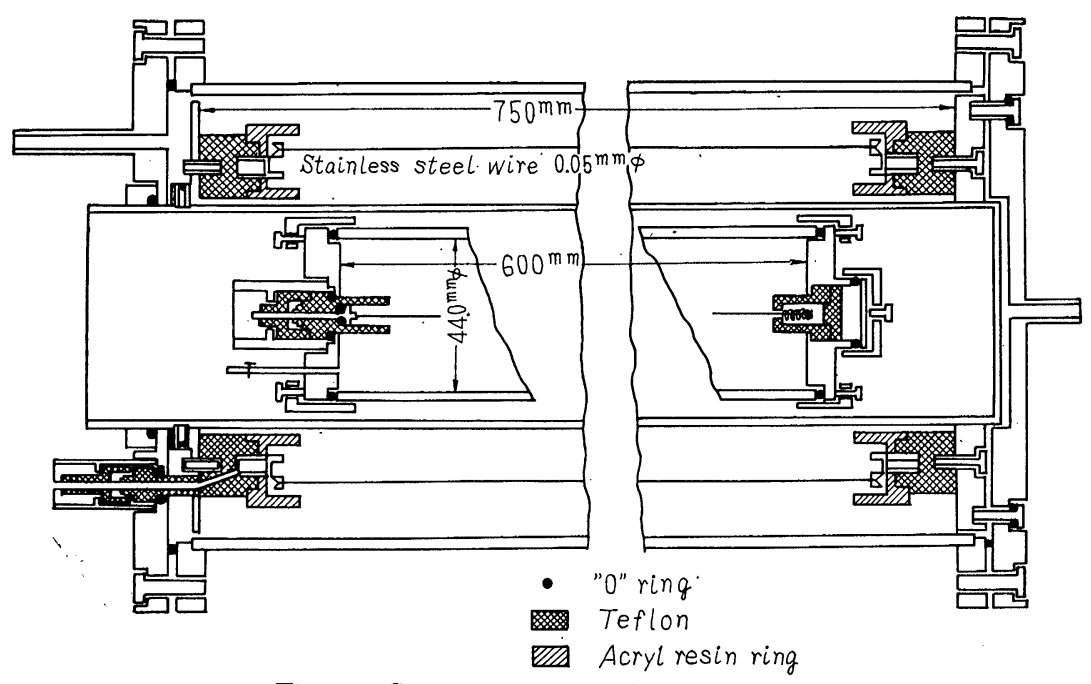

Fig. 3 Center counter and outer counter

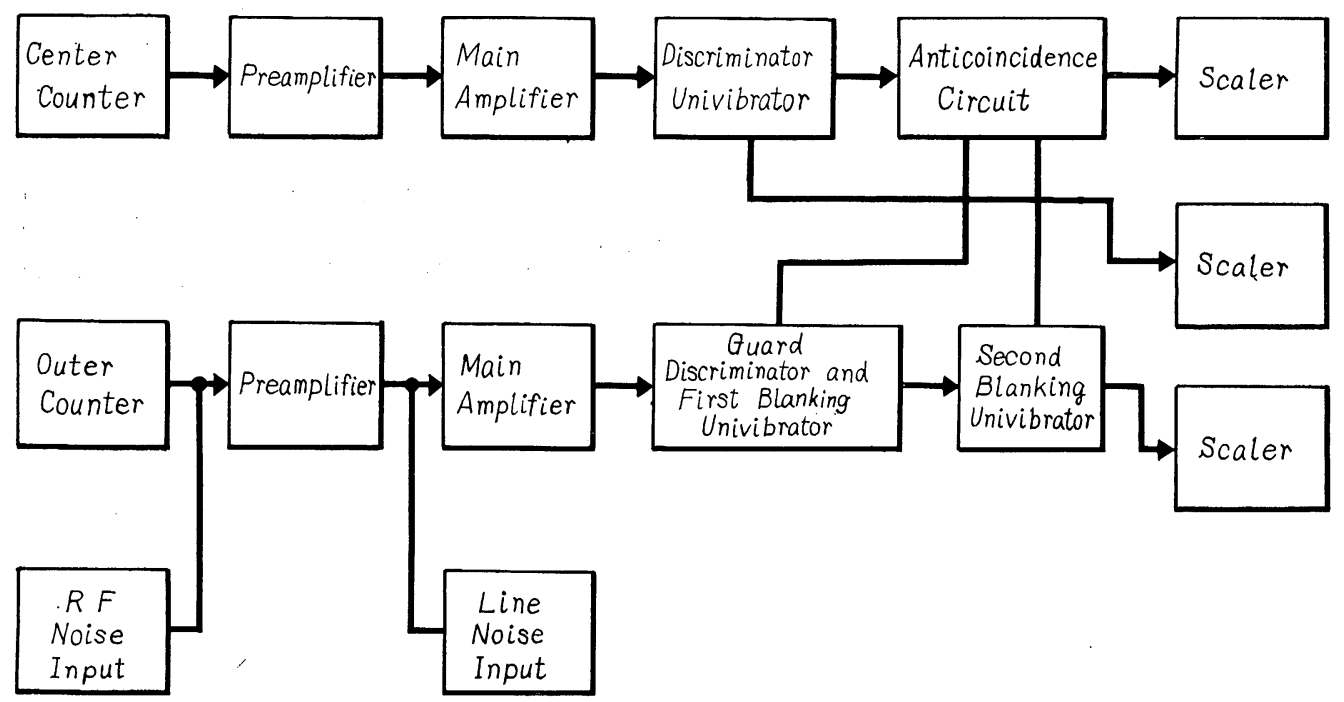

Fig. 4 Block diagram of the electronic system

中心に径 $0.005 \mathrm{~cm}$ のステンレス線が張られ，体積は約 $921 \mathrm{~cm}^{2}$ である。

(ロ) シールド用比例計数管

中心比例計数管の外侧にあって, 径 $12.8 \mathrm{~cm}$, 長さ 75 $\mathrm{cm}$ のステシレス管に 20 本の直径 $0.005 \mathrm{~cm}$ のステンレス 線を円状のアクリル樹脂板に張った multi-anode 比例計 数管である。

\section{6 測定機の調整について}

中心 counter し, 電圧を徐々に増すと count 数も増し大体 $5 \mathrm{kV}$ で150 counts/min となり, その後電圧を增しても一定で Plateau 域を形成する。さらに電圧を増すと連続放電域と なる。この各圧力に批けるプラト一曲線から operating voltage を定めているが，プラトーの始まる電圧に $300 \mathrm{~V}$ を加えた值を用いた（図一 5 参照）。
同じようにして outer counter Kメタンガスおよびプ ロパンガスを流したまま宇宙線によって遊離される電子 を前と同じ原理に従ってプラト一曲線を求めているが， 4. $6 \sim 5.6 \mathrm{kV}$ の約 $1 \mathrm{kV}$ 範囲にプラトー部があり counter 特性として良好なことを示している。

次に outer counter がぞこまで効果的に外部からの宇 宙線の影響を除く働きをするかを確認してみた。center counter 1 気圧の $\mathrm{CO}_{2}$ を封入して電圧を上げていくと 電圧の上昇と共に count 数も增加し, 180c.p.m で一定 となり $3.6 \sim 4.1 \mathrm{kV}$ までプラトーが続いていることが分 る (図-6 参照)。この 180 c.p.m は $\mathrm{CO}_{2}$ 内の放射能と宇 宙線の総和である。次に outer counter にメタン, また はプロパンガスを流しながら outer counter の電圧を上 げていくと宇宙線による count 数も電圧の上昇と共に増 加し約 800c.p.m で一定となり $4.8 \mathrm{kV}$ より $5.5 \mathrm{kV}$ までプ 


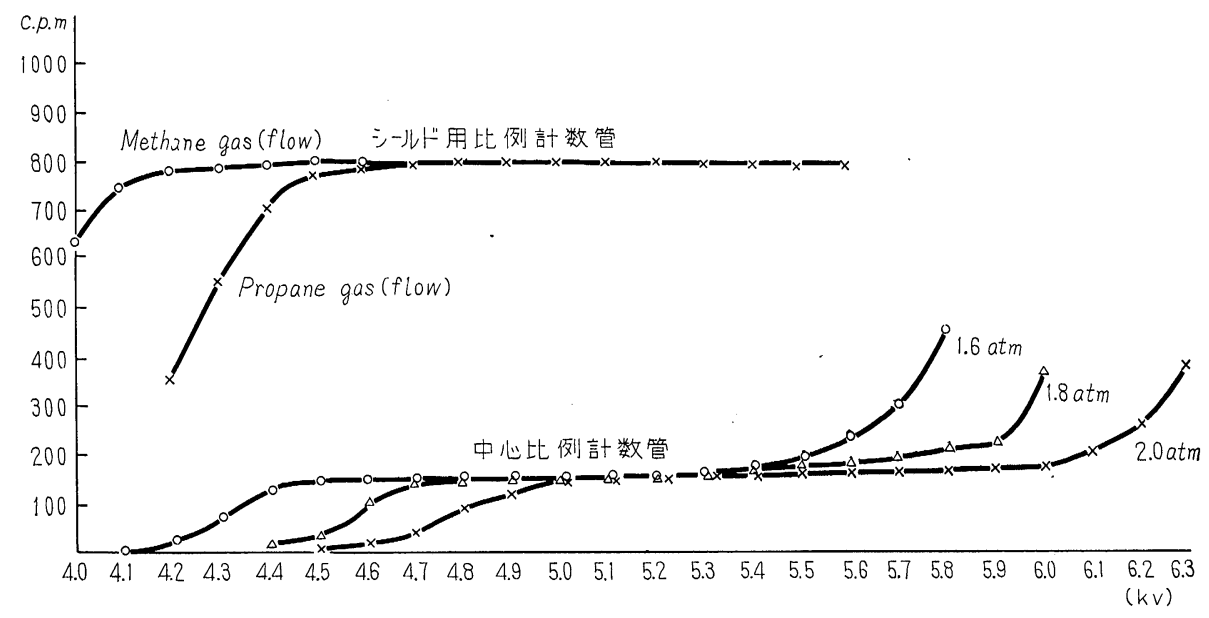

Fig. 5 The plateau curves of the center and outer counter

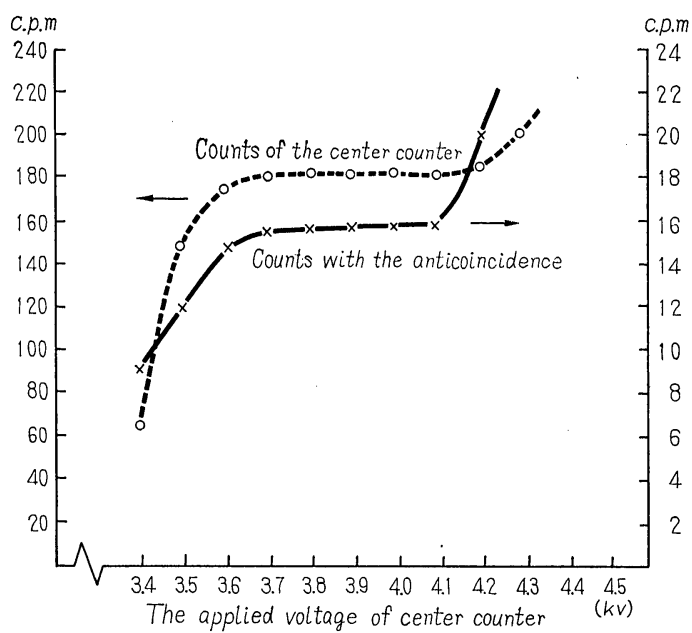

Fig. 6 Counts of the center with and without the anticoincidence when the applied voltage is varied

ラトーが続いている。次に両方の counter を働かすので あるが，先に求めた center counter の operating voltage

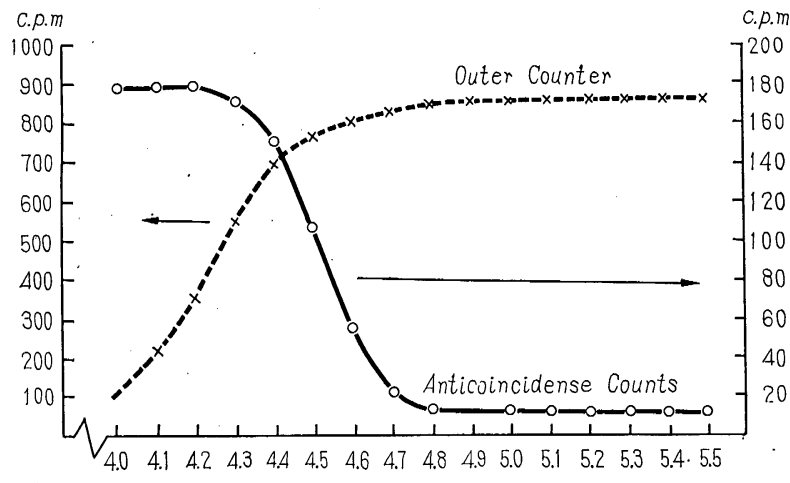

Fig. 7 Counts of the center counter with anticoincidence when the voltage of the outer counter
を最初から center counterに与え outer counter の尓は 電圧を次第に上げていって center counter の count 数 を求めると anticoincidence が利いていない 180c.p.m か ら始まって anticoincidence の作用と共に count 数が減 少し大体 16c.p.m に落着いて一定となる。このときの outer counter の operating voltage は 4.8〜5.3kVであ る。したがって，この測定より anticoincidence が效い ていることおよび center counter に1気圧の試料をい れたときの両 counter の operating voltage 域を決定で きる(図-7)。

最後にこのようにして, 各種気王のもとに执いて測定 した結果を図にプロットし零気圧のときの值を推定する と Dead Carbon の c.p.m と一致するかどらか確認して, 测定絬果の信頼度を確かめている（図-8)。

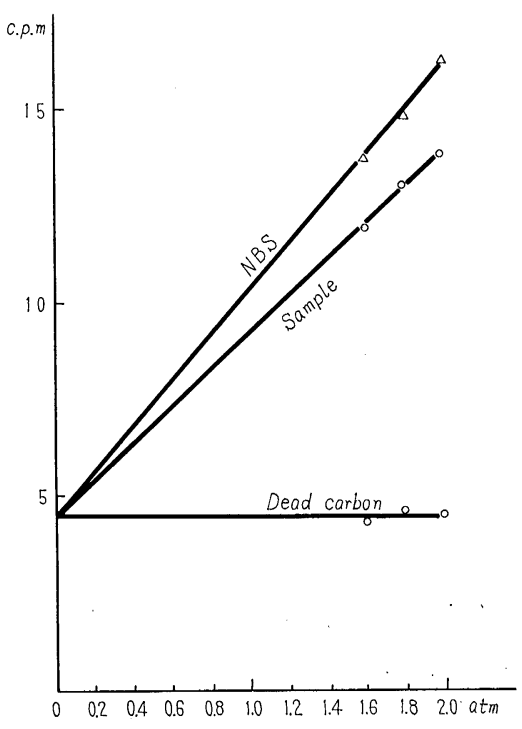

Fig. 8 Pressure test of the center counter 


\section{1 測定結果およひ得られた結果}

(1) Sample の封入気圧

$$
\begin{aligned}
& P_{1}=1520 \mathrm{~mm}-\mathrm{Hg} \\
& P_{2}=1368 \mathrm{~mm}-\mathrm{Hg} \\
& P_{3}=1216 \mathrm{~mm}-\mathrm{Hg}
\end{aligned}
$$

(ㅁ) Operating voltage

$V_{1}=5.3 \mathrm{kV}$

$V_{2}=5.1 \mathrm{kV}$

$V_{3}=4.6 \mathrm{kV}$

outer counter はすべて $4.7 \mathrm{kV}$

(价 测定時間

$t_{1}=1175 \mathrm{~min}$

$t_{2}=1081 \mathrm{~min}$.

$t_{3}=915 \mathrm{~min}$.

$\Leftrightarrow$ 測定時の温度

$T_{1}=273+22$

$T_{2}=273+20$

$T_{3}=273+20$

(本) $0^{\circ} \mathrm{C}$ 一の換算圧力

$P_{01}=1407 \mathrm{~mm}-\mathrm{Hg}$

$P_{02}=1275 \mathrm{~mm}-\mathrm{Hg}$

$P_{03}=1133 \mathrm{~mm}-\mathrm{Hg}$

(i) Gross counts

$N_{1}=13.85 \pm 0.11$ c.p.m

$N_{2}=13.01 \pm 0.11$ c.p.m

$N_{3}=11.92 \pm 0.11$ c.p.m

(i) Back counts

$N_{b 1}=4.51 \pm 0.06$ c.p.m

$N_{b 2}=4.57 \pm 0.06$ c.p.m

$N_{b 3}=4.37 \pm 0.05$ c.p.m

(f) Net counts

$n_{1}=9.34 \pm 0.11$ c.p.m

$n_{2}=8.44 \pm 0.11$ c.p.m

$n_{3}=7.55 \pm 0.11$ c.p.m

(リ) Net counts $00^{\circ} \mathrm{C}$ に打ける気圧数で制り $1 \mathrm{~mm}$ -

$\mathrm{Hg}$ の count 数を求める

$n_{01}=0.006638$ c.p.m $/ \mathrm{mmHg}$

$n_{02}=0.006620 \mathrm{c} \cdot \mathrm{p} \cdot \mathrm{m} / \mathrm{mmHg}$

$n_{03}=0.006664$ c.p.m $/ \mathrm{mmHg}$

$\bar{n}_{0}=\frac{n_{01}+n_{02}+n_{03}}{3}=0.006641$ c.p.m $/ \mathrm{mmHg}$

(又) N B.S \&同様に $0^{\circ} \mathrm{C}$ に補正して平均する

$N_{1}{ }^{\prime}=16.27$ c.p.m

$N_{2}{ }^{\prime}=14.96$ c.p.m

$N_{3}{ }^{\prime}=13.80$ c.p.m

$n_{01}{ }^{\prime}=0.08418$ c.p.m $/ \mathrm{mmHg}$

$n_{02}{ }^{\prime}=0.008279$ c.p.m $/ \mathrm{mmHg}$

$n_{03}{ }^{\prime}=0.008187$ c.p.m $/ \mathrm{mmHg}$

$\bar{n}_{0}{ }^{\prime}=0.008295$ c.p.m $/ \mathrm{mmHg}$
（ル） N.B.Sは dating の場合95\%として計算する $x=\frac{\bar{n}_{0}}{0.95 \times \bar{n}_{0}^{\prime}}=0.8428$ c.p.m $/ \mathrm{mmHg}$

(ᄏ) 年代 $t$ は

$$
t=5570 \times \frac{\log 0.8428}{\log 1 / 2}=5570 \times \frac{0.07428}{0.3010}=1370
$$

(ワ) 標準偏差の式を展開して誤差範囲をきめるが，今 までの測定結果を計算してみると大体約 $3 \%$ に落ち

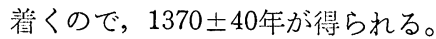

\section{§4. 地すべりの周期について}

日本の地すべりは，ほとんどの埸合旧地すべりの跡に 生じている。ということは各地域に周期的に発生するこ とが予想される。すなわち周期は大地すべりによって文 定化した地盤が，風化，地盤変動，堆積，浸蝕などの過 程を通じて再び不努定になるまでの期間で，当然地貿， 地形，気候その他あらゆる要因の影響を受けるので一概 に推定することはできない。しかし大地すべりが起って 数年後に再び大地すべりが発生するとは誰も思わない。 胡桃や目比の地すべり地に再び大崩壊が近い将来起ると は思光ない。しかしあと数百年先になるとどらか分らな い。そらいら钼点から考光ると木屋平の 15400 年，水沢 新田の $1370 \pm 40$ 年は大体の地すべりの周期の桁を喑示す るものであろうか。

日本の地すべり地は大体6000個所といわれている。そ こで地すべり性大崩壊の生ずる凬期が，1000年に 1 回， 2000 年に 1 回，15000 年に 1 回あるとして，それぞれの 場合について年間発生件数の確漆を計算してみた。た えば2000年に 1 回の周期で発生する場合, 年間 $n$ 回発生 する確率は

$$
{ }_{6000} C_{n}\left(\frac{1}{2000}\right)^{n}\left(\frac{1999}{2000}\right)^{6000-n}
$$

である。

$$
\begin{aligned}
& \text { ここに } \\
& { }_{6000} C_{n}=\frac{6000 !}{n !(6000-n) !}
\end{aligned}
$$

である。

この式によって計算した結果を表ー 1 および図-9 亿示 す。

1000年周期では年 5 回, 6 回発生の碓率が最大, 2000 年周期では年 2 回, 3 回発生の確率が最大, 15000 年周 期ではむしろ発生しない年の方が多いという結果にな り，発生件数が少な過ぎる感じもする。しかし写点- 3 に示すような大樹が埋れるような大崩壊性地すべりの発 生はそんなに多くなく，年数回というのは正しいという ような感じもする。もしそうとすると崩塤性地すべりの 閏期は千年の桁となり，われわれが潜在的に考えていた 数十年周期の概念を大きく恋えねばならないと思ら。 
地すべり Vol. 7, No. 3 (通巻 第 23 号)

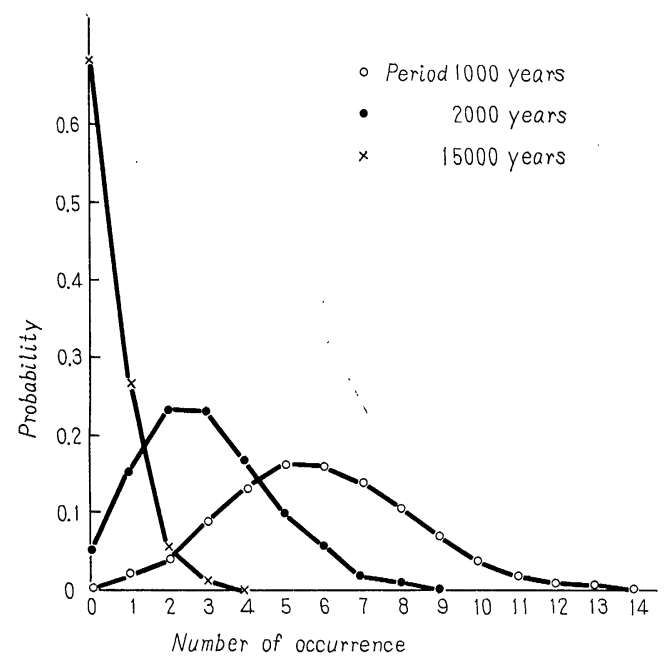

Fig. 9 Probability of occurrence of large failure type landslide

\section{§5．＼cjkstart結＼cjkstart語}

年代測定の技術は非常に有効で各分野にわたって面白 い畑識を供給して呉れる。しかし奉際の測定技術はなか なか難かしく，信頼できる結果を出してくれるところは 世界でも数が少ない。そのせいか游壊性地すべりの中か ら発見された埋术の年代測定がなされたことは今までき いたことがなかったが，ここに発表された $1370 \pm 40$ 年は 信頼の淤ける值である。これくらいの值が搠䏅性地すべ りの閭期と考学ると，日本での年間発生率は平均 4 回前 後である。大木が埋れるくらいの大崩壊であるので，こ れも案外正しい值かも知れない。インドネシアは非常に 地すべりの多いところであるのは日本人技術者の方が良
表-1 発生確率表

\begin{tabular}{c|c|c|c}
\hline \hline $\begin{array}{c}\text { 発生脌数 } \\
\text { 年当 }\end{array}$ & 1000年周期 & 2000年周期 & 15000年周期 \\
\hline 0 & 0.00 & 0.05 & 0.68 \\
1 & 0.02 & 0.15 & 0.27 \\
2 & 0.04 & 0.23 & 0.05 \\
3 & 0.09 & 0.23 & 0.01 \\
4 & 0.13 & 0.17 & 0.00 \\
5 & 0.16 & 0.10 & \\
6 & 0.16 & 0.06 & \\
7 & 0.14 & 0.02 & \\
8 & 0.11 & 0.01 & \\
9 & 0.07 & 0.00 & \\
10 & 0.04 & & \\
11 & 0.02 & & \\
12 & 0.01 & & \\
13 & 0.01 & & \\
14 & 0.00 & & \\
\hline
\end{tabular}

く知っているが，あちらの地啠調査所の担当官に尋ねる と，年間 5 回ぐらいの発生だと答えていたが彼の頭の中 にやはり，こらいら大崩壊性の地すべりを頭に画いたか らであろらか。

今後さらに地すべり地中の埋木の年代測定を続けたい ので，御存知の方があれば扮知らせ頂きたい。

この測定を心よく許可し御協力下さった台湾大学物理 教室許雲基教授。測定および計算のお括話になった同黄

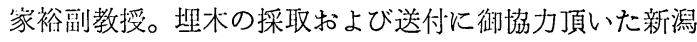
県小千谷土木事務所横山好堆所長, 京都大学防災研究所 高田雄次助教授に厚く謝意を表したい。 